\title{
PGE-bearing mafic-ultramafic sills in the floor of the eastern Bushveld Complex on the farms Blaauwboschkraal, Zwartkopje, and Waterval
}

\author{
W.D. Maier \\ Centre for Research on Magmatic Ore Deposits, Department of Geology, University of Pretoria, Pretoria 0002, \\ e-mail:wdmaier@scientia.up.ac.za \\ J. Sliep \\ ISCOR Ltd., PO Box 450, Pretoria 0001 \\ Sarah-Jane Barnes \\ Sciences de la terre, Université du Québec, Chicoutimi G7H 2B1, Canada, \\ e-mail: sjbarnes@uqac.uquebec.ca \\ S.A. de Waal \\ Centre for Research on Magmatic Ore Deposits, Department of Geology, University of Pretoria, Pretoria 0002 \\ e-mail: sadw@scientia.up.ac.za \\ C. $\mathrm{Li}$ \\ Department of Geological Sciences, University of Indiana, Bloomington, IN 47405, USA \\ e-mail:cli@indiana.edu
}

\begin{abstract}
Mafic-ultramafic sills of up to $450 \mathrm{~m}$ in thickness occur near the contact between sedimentary and volcanic rocks of the Silverton Formation, Transvaal Supergroup, on the farms Blaauwboschkraal, Zwartkopje and Waterval, some $10 \mathrm{~km}$ north of Waterval Boven in the Mpumalanga Province. The sills consist of peridotite, harzburgite, pyroxenite and gabbro, and may locally contain up to about $10 \%$ Ni-Cu-PGE sulphides. Metal contents of the rocks reach $0.7 \%$ $\mathrm{Cu}, 0.8 \% \mathrm{Ni}$, and $2 \mathrm{ppm}$ PGE. Sulphides are found at variable levels within the intrusions and are interpreted to have precipitated from distinct surges of magma streaming through a conduit. This model is analogous to that proposed for the Uitkomst Complex, which hosts sulphides of broadly similar composition to the present bodies and which consists of broadly similar lithologies, apart from the presence of chromitite in the latter. The lithological and compositional similarities between the intrusions raise the possibility of undiscovered economic sulphide concentrations in the present bodies. However, olivines in most of the ultramafic rocks are undepleted in $\mathrm{Ni}$, suggesting that either sulphide segregation was minor and localized, or that any metal-depleted magmas were flushed out of the conduit by undepleted magma.
\end{abstract}

\section{Introduction}

The discovery of economically important massive sulphides in the Uitkomst Complex in 1990 (Gauert et al., 1995) has triggered considerable exploration activity for magmatic sulphide ores in the floor of the eastern Bushveld Complex. In particular, exploration has targeted sill and dyke-like bodies that may represent magma conduits (e.g. the Wanhoop intrusion, Schürmann, 1992). This is because the Uitkomst sulphides and other major magmatic sulphide ores elsewhere (Voisey's Bay; Noril'sk) are now understood to be hosted by dynamic magma conduits systems (Naldrett, 1997).

The sill-like bodies on the farms Blaauwboschkraal $346 \mathrm{JL}$, Waterval $331 \mathrm{JT}$, and Zwartkopje 329 JT studied here appear to offer particular potential for magmatic sulphide ores due to lithological similarities to the Uitkomst Complex, and a common broad alignment with the Uitkomst Complex to a prominent set of faults indicated on the regional geological maps.
We present lithological descriptions of the bodies as well as major and trace element data, including PGE. Based on these data we attempt to constrain the origin of the sulphide mineralization and the potential of the bodies to host more important sulphide ores.

\section{Regional geology and exploration history}

A geological map of the Waterval Boven-Machadodorp area is shown in Figure 1 and the regional stratigraphy is summarised in Table 1 . The rocks of the region form part of the Pretoria Group of the Transvaal Supergroup, which dip at an angle of 5 to $10^{\circ}$ to the west and strike broadly north to south. The farm Blaauwboschkraal $346 \mathrm{JL}$ is located some $10 \mathrm{~km}$ to the north of Waterval Boven, $150 \mathrm{~km}$ due east of Pretoria. Sulphide-bearing mafic-ultramafic rocks on Blaauwboschkraal were initially discovered in a borrow pit during construction of the Schoemanskloof road, in the 1970s. Subsequent drilling by GEMEX in the late 1970s and early 1980s delineated an easterly plunging sill-like body (termed 


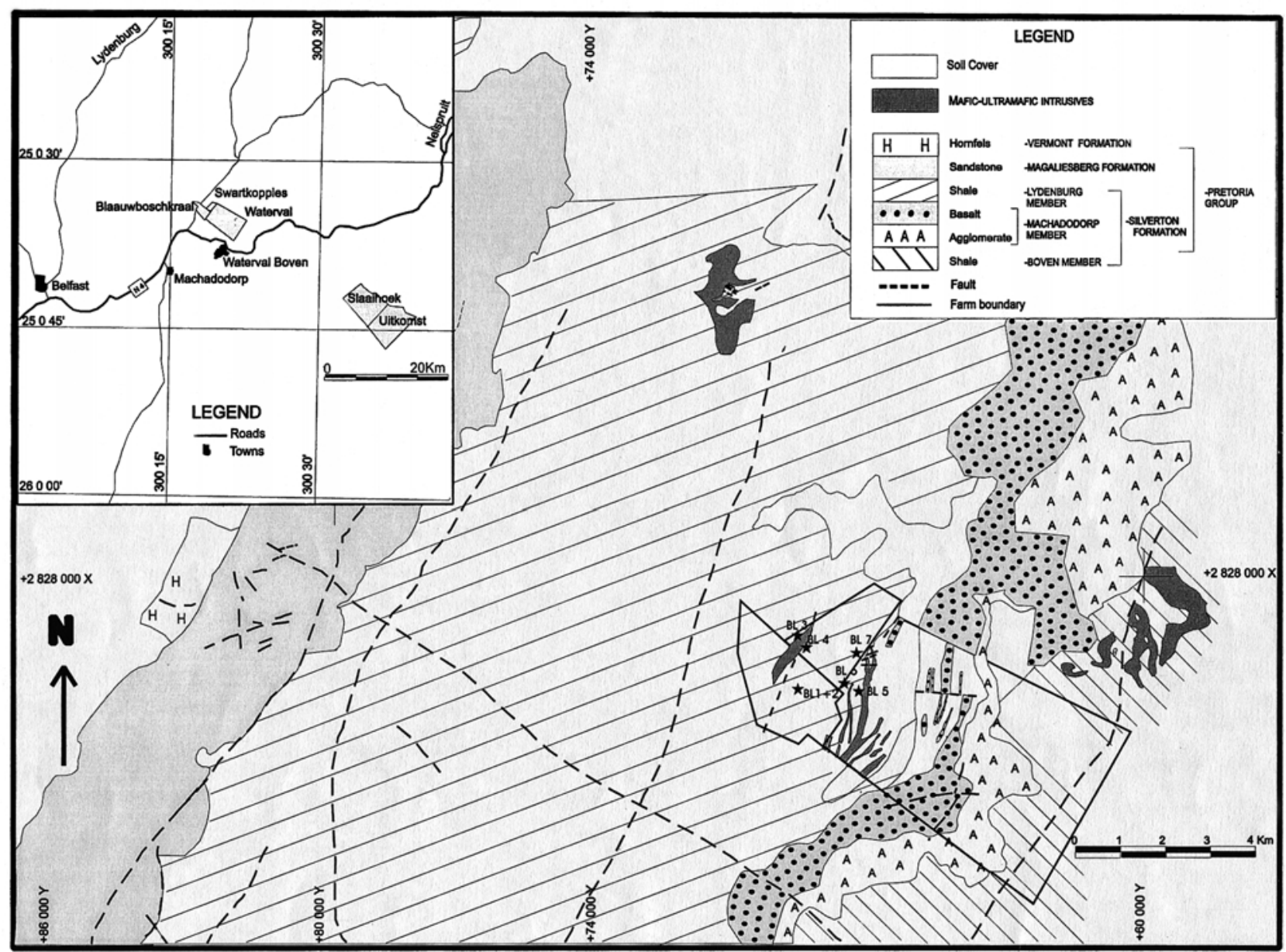

Figure 1. Locality map, containing farm boundaries and sites of borehole collars.

the Helvetia body) that intruded into shales of the Lydenburg Member (Figure 2). In 1996, ISCOR Ltd. went into a joint venture project with $\mathrm{B} \& \mathrm{~B}$ Consortium. Additional drilling provided a deeper intersection of the body (borehole BL1) and also intersected a second, larger, westerly-plunging, mafic-ultramafic body in the footwall (borehole BL2) that intruded broadly conformably along the contact between the shales and the underlying Machadodorp volcanic rocks. A third borehole (BL3) collared some $1000 \mathrm{~m}$ to the north merely intersected a number of thin slivers of gabbro and pyroxenite in shale. Based on field mapping, geochemical soil sampling and magnetic and electromagnetic (EM34) surveys that outlined gabbroic bodies and an associated long wavelength, low amplitude magnetic anomaly on the adjoining farms Zwartkopje 329JT and Waterval 331JT, four further diamond boreholes were drilled by ISCOR (BL4 to 7; Figure 1). These holes intersected mafic-ultramafic intrusions similar in lithology and thickness to those on Blaauwboschkraal (Figure 3), but with a thinning of the bodies observed in the northernmost hole (BL7). The borehole data suggest the presence of a sill-like body with a width of at least $1.5 \mathrm{~km}$ and a maximum thickness of around $450 \mathrm{~m}$ that plunges to the northwest at a shallow angle broadly conformable to the dip of the Transvaal sedimentary rocks.

The farm Blaauwboschkraal is situated some $4 \mathrm{~km}$ to the north of a major northwest to southeast trending fault (Figure 1), and the area also contains a number of

Table 1. Regional stratigraphy in the Waterval Boven - Machadodorp area

\begin{tabular}{|c|c|c|c|c|}
\hline Sequence & Group & Formation & Member & Main Rock Type \\
\hline & & Vermont & & Hornfels \\
\hline & & Magaliesberg & & Quartzite, sandstone \\
\hline & & & Lydenburg & Shale \\
\hline \multirow[t]{4}{*}{ Transvaal } & Pretoria & Silverton & Machadodorp & Basalt, agglomerate \\
\hline & & & Boven & Shale \\
\hline & & Daspoort & & Quartzite \\
\hline & & Strubenkop & & Shale, sandstone \\
\hline
\end{tabular}




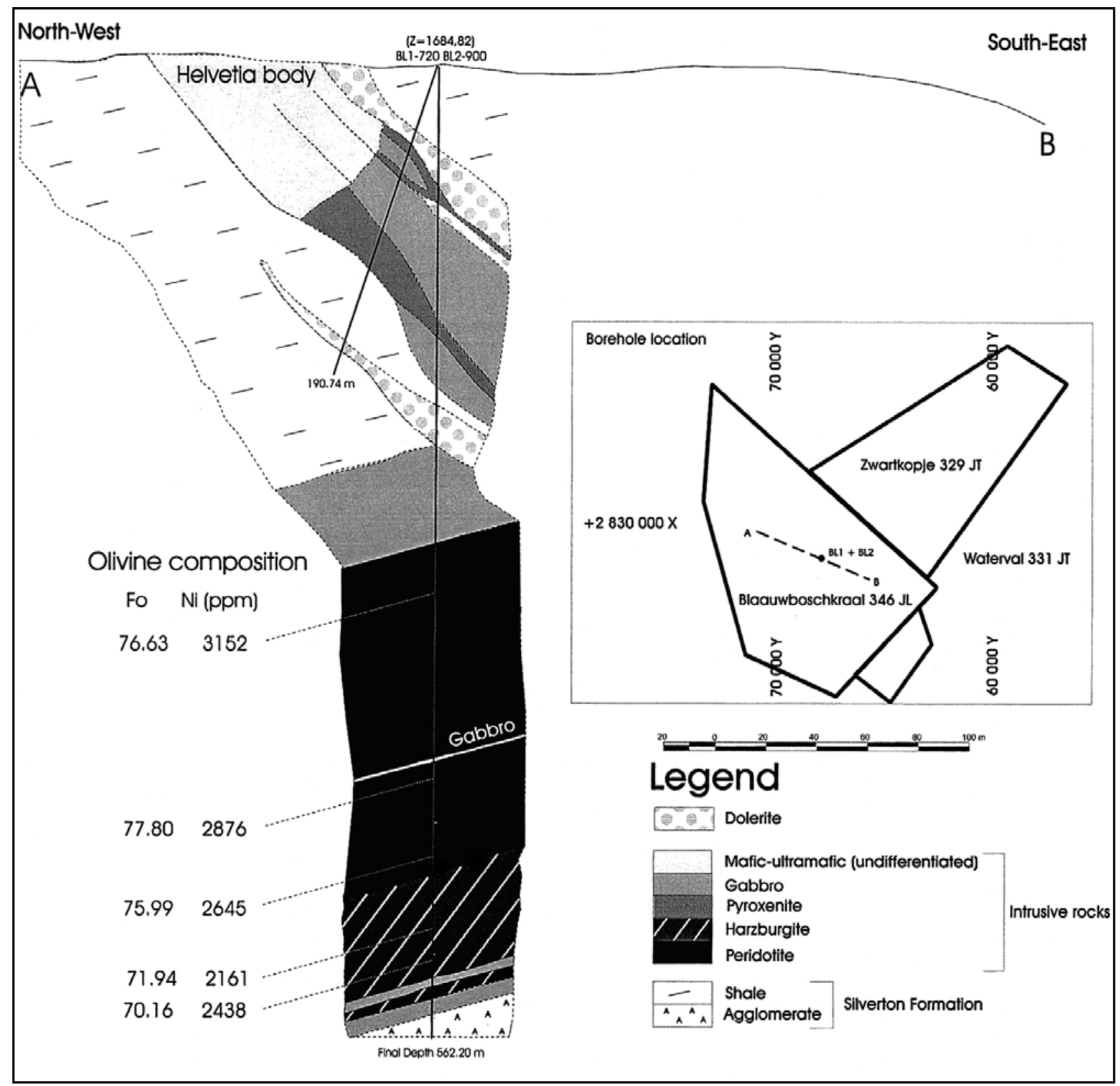

Figure 2. Cross section through the Helvetia body and the underlying main body. Sample numbers for olivine data are given in the text.

less prominent northeast trending faults, 2 of which bound the Helvetia body.

\section{Borehole description}

A section through boreholes BL1 and BL2 is shown in Figure 2, and borehole logs are listed in Table 2. In borehole BL1, the Helvetia body consists of a basal $25 \mathrm{~m}$ of olivine-pyroxenite containing lenses and layers of peridotite. This unit is locally brecciated and intensely altered to an assemblage consisting of amphibole, serpentine and chlorite. The olivine-pyroxenite and its immediate sedimentary footwall may contain up to about 10\% Cu-Ni sulphides (essentially pyrrhotite, chalcopyrite and pentlandite). The sulphides occur disseminated and in veinlets. In contrast, the peridotite layers are poor in sulphides. We estimated the approximate primary magmatic volume proportions of the major silicate phases in the altered olivinepyroxenites by means of CIPW norm calculations and binary oxide variation diagrams. The rocks originally contained approximately 40 to $60 \%$ orthopyroxene, 10 to $20 \%$ olivine, 10 to $20 \%$ clinopyroxene, and 10 to $15 \%$ plagioclase. Modal estimates can not yet be provided for the altered peridotite layers due to a lack of chemical data. The ultramafic unit is overlain by some $48 \mathrm{~m}$ of gabbro that contain 2 layers of pervasively altered ultramafic breccia, 2 to $3 \mathrm{~m}$ in thickness. Neither ultramafic layer contains visible sulphides. The gabbros are less altered than the ultramafic rocks and their mineralogy, as determined by petrographic observation, 
Table 2. Logs of boreholes BL1 and BL2

\begin{tabular}{|c|c|c|c|c|c|}
\hline \multicolumn{3}{|l|}{ BL1 } & \multicolumn{3}{|l|}{ BL2 } \\
\hline $0.00-$ & 40.74 & Shale & $0.00-$ & 47.37 & Shale \\
\hline $40.74-$ & 49.11 & Dolerite & $47.37-$ & 68.18 & Dolerite \\
\hline $49.11-$ & 52.62 & Mafic-ultramafic breccia & $68.18-$ & 78.64 & Mafic-ultramafic breccia \\
\hline $52.62-$ & 65.82 & Gabbro & $78.64-$ & 86.67 & Dolerite \\
\hline $65.82-$ & 67.52 & Pyroxenite & $86.67-$ & 141.90 & Gabbro \\
\hline $67.52-$ & 97.85 & Gabbro & $141.90-$ & 154.62 & Pyroxenite (brecciated) \\
\hline \multirow[t]{2}{*}{97.85 - } & 122.75 & Pyroxenite (brecciated), & $154.62-$ & 161.57 & Gabbro \\
\hline & & with lenses of harzburgite & $161.57-$ & 181.60 & Gabbro \\
\hline \multirow[t]{2}{*}{$122.75-$} & 165.16 & Shale, with minor & $181.60-$ & 183.98 & Gabbro \\
\hline & & gabbro & $183.98-$ & 194.25 & Shale \\
\hline $165.16-$ & 173.42 & Dolerite & $194.25-$ & 217.65 & Dolerite \\
\hline \multirow[t]{7}{*}{$173.42-$} & 190.74 & Shale & $217.65-$ & 274.87 & Gabbro, with siltstone xenoliths at base \\
\hline & & & $274.87-$ & 465.00 & Peridotite, with gabbro from 398.16-399.59 \\
\hline & & & $465.00-$ & 525.27 & Feldspathic harzburgite with numerous xenoliths near base \\
\hline & & & $525.27-$ & 529.62 & Gabbro \\
\hline & & & $529.62-$ & 535.12 & Feldspathic harzburgite with xenolith of gabbro at 533.75 \\
\hline & & & $535.12-$ & 544.45 & Gabbro with siltstone xenoliths \\
\hline & & & $544.45-$ & 562.20 & Volcanic agglomerate \\
\hline
\end{tabular}

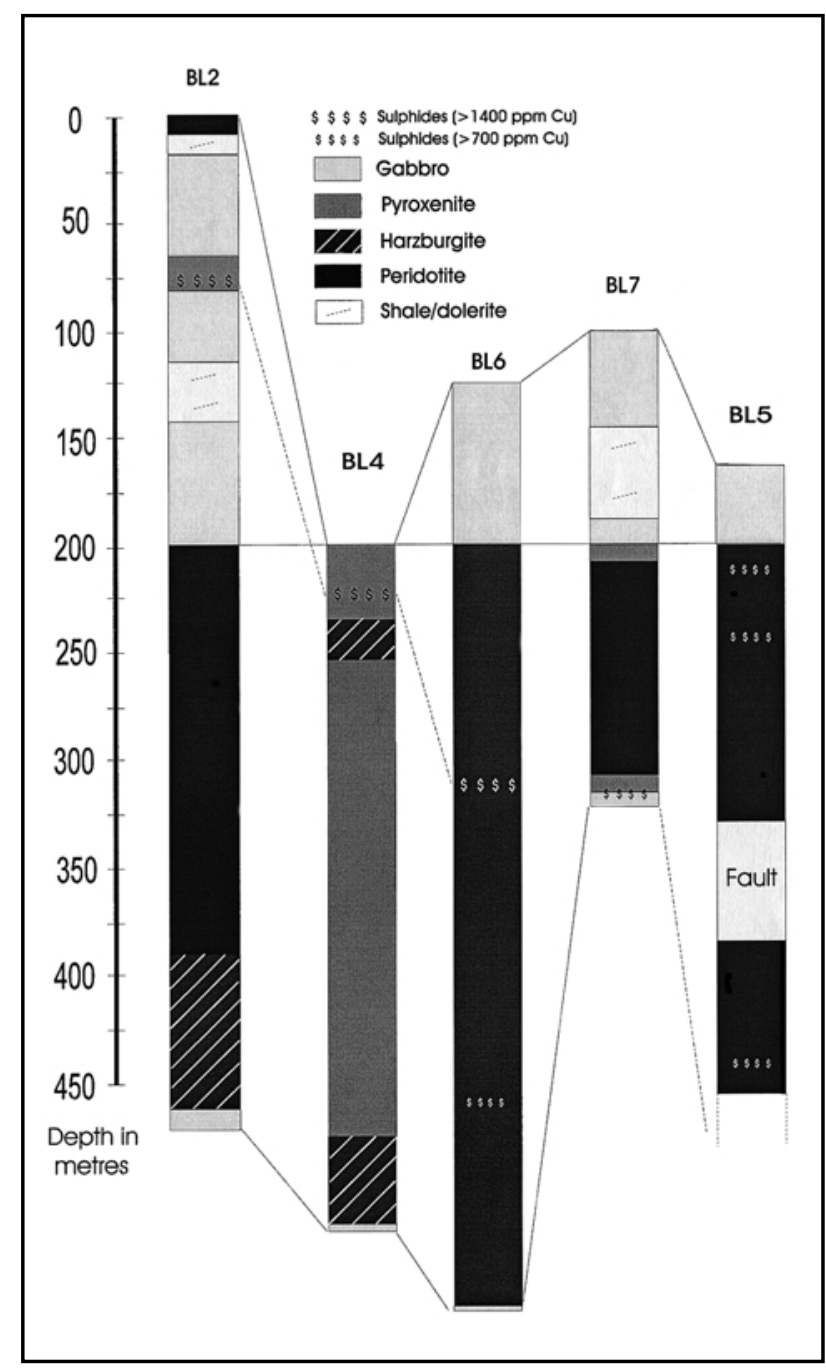

Figure 3. Stratigraphic and lithological comparison of the studied mafic-ultramafic sill, as intersected by boreholes BL2 and 4 to 7 . See Figure 1 for borehole localities. is approximately 50\% plagioclase, 30\% orthopyroxene, and $20 \%$ clinopyroxene. The immediate hanging wall of the Helvetia body consists of dolerite.

In borehole BL2, the thickness of the Helvetia body is similar to that in borehole BL1, but the basal ultramafic layer is only $13 \mathrm{~m}$ thick and is underlain by gabbro. Further, only one additional ultramafic layer was intersected near the top contact of the body. Sulphides occur in the basal ultramafic layer, in broadly similar form and concentration as in BL1.

The lower or main intrusion was intersected by borehole BL2 some $33 \mathrm{~m}$ below the Helvetia body and has a total thickness of $327 \mathrm{~m}$. Based on the difference in plunge between the Helvetia body and the main intrusion, it appears that the Helvetia body may represent a tongue-like offshoot from the main intrusion.

The main intrusion is relatively unaltered. It's lower portion consists of $10 \mathrm{~m}$ of basal gabbro, overlain by $5 \mathrm{~m}$ of feldspathic harzburgite, another $5 \mathrm{~m}$ of gabbro, and a further $55 \mathrm{~m}$ of feldspathic harzburgite. The basal 20 to $30 \mathrm{~m}$ of the intrusion contain several xenoliths of siltstone. The basal gabbro has a similar mineralogy to the Helvetia gabbro. The harzburgite consists of approximately 40 to $50 \%$ olivine, $10 \%$ each orthopyroxene and clinopyroxene, 20\% plagioclase, and up to $5 \%$ K-feldspar. Notably, the harzburgite contains disseminated sulphides (pyrrhotite, chalcopyrite, pentlandite) throughout its width, reaching about 2 to 3 volume $\%$. The central portion of the main intrusion consists of $190 \mathrm{~m}$ of peridotite containing a $1 \mathrm{~m}$ gabbro layer at about mid-level. The mineral mode of the peridotite is approximately $75 \%$ olivine, $10 \%$ orthopyroxene, 5 to $10 \%$ plagioclase, and 2 to $5 \%$ clinopyroxene. The uppermost portion of the main intrusion is formed by some $55 \mathrm{~m}$ of fine-grained to pegmatoidal gabbro containing several thin (1 to $30 \mathrm{~mm}$ ) 


\section{BL 2}

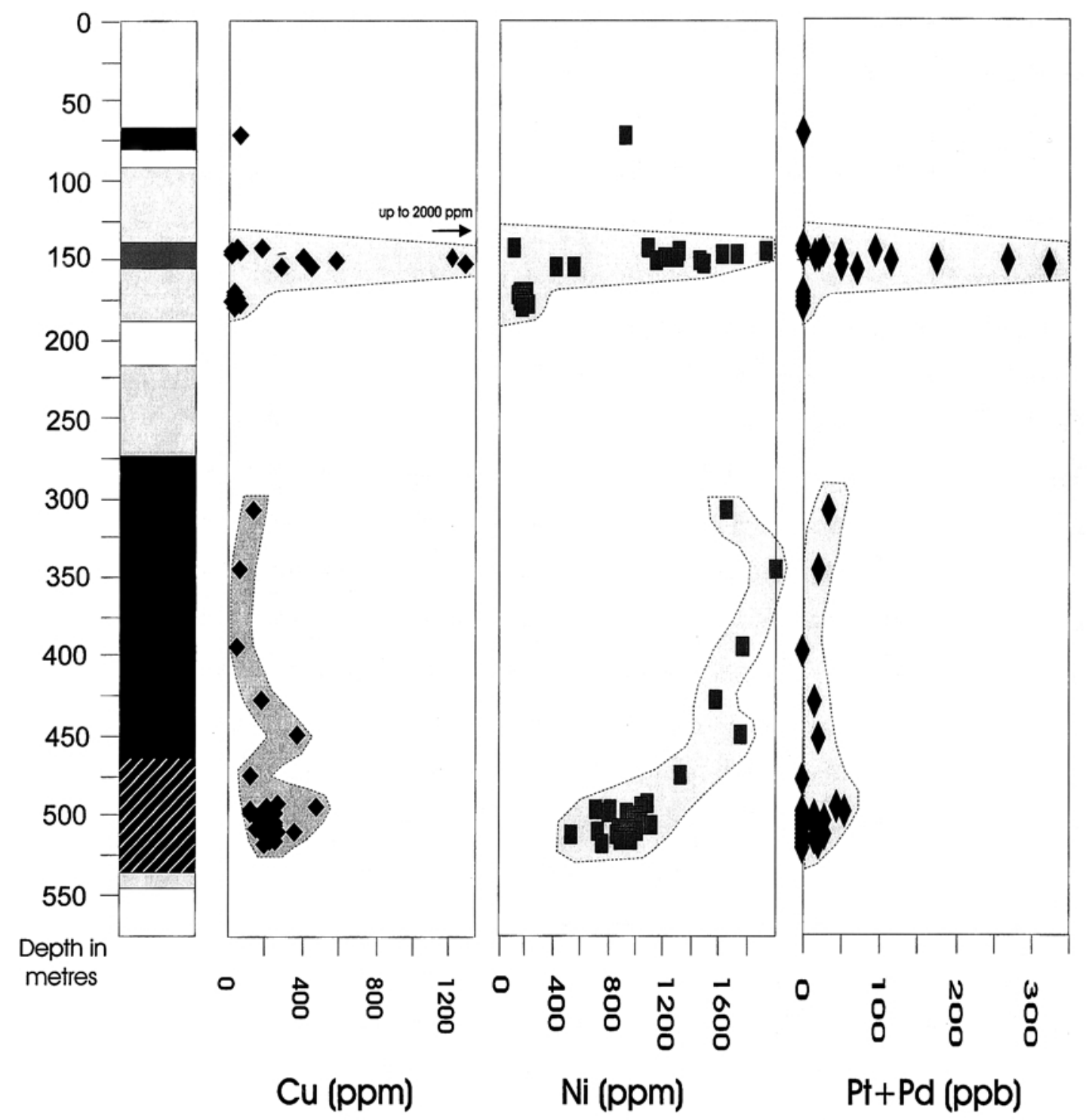

Figure 4. Compositional variation of $\mathrm{Cu}, \mathrm{Ni}$ and $\mathrm{Pt}+\mathrm{Pd}$ versus stratigraphic height in borehole BL2.

magnetite layers. Both the peridotite and gabbro appear to be largely sulphide-free, except for minor concentrations of disseminated sulphide in some samples near the base of the peridotite.

The mafic-ultramafic bodies intersected by boreholes BL1 to 2 and 4 to 7 are compared in terms of their stratigraphy and lithology in Figure 3. In most boreholes, the intrusions consist of a central ultramafic unit bounded by gabbro at the base and top. However, in boreholes BL2 and BL7, the upper gabbroic phase has bifurcated into two layers, separated by a parting of shale. In addition, there are several distinct ultramafic layers found in the upper gabbro of boreholes BL1 and
BL2, which are not developed in the remaining borehole intersections. Further lateral variation between the borehole intersections is manifested by the occurrence of minor disseminated sulphides within the central ultramafic portion in boreholes BL4, 5, and 6. The combined thickness of the bodies varies between 155 and $380 \mathrm{~m}$. The observed thickness is lowest in the northernmost borehole (BL 7), suggesting that the body pinches out in this direction.

\section{Analytical results}

Concentrations of $\mathrm{Cu}, \mathrm{Ni}, \mathrm{Pt}, \mathrm{Pd}, \mathrm{Au}, \mathrm{Cr}$ and $\mathrm{Co}$ in 56 samples of borehole BL2 and 20 samples of BL1 were 
Table 3. Metal contents in borehole BL1

\begin{tabular}{|c|c|c|c|c|c|c|c|c|}
\hline from & to & Cu (ppm) & Ni (ppm) & Pt (ppb) & Pd (ppb) & Au (ppb) & Cr (ppm) & Co (ppm) \\
\hline $60.00-$ & 61.00 & 169 & 224 & $<10$ & $<10$ & $<10$ & 63 & 35 \\
\hline $64.00-$ & 65.00 & 151 & 191 & $<10$ & $<10$ & $<10$ & 78 & 34 \\
\hline 70.00- & 71.00 & 154 & 193 & $<10$ & $<10$ & $<10$ & 86 & 32 \\
\hline $103.74-$ & 105.80 & 49 & 1570 & $<10$ & $<10$ & $<10$ & 1180 & 109 \\
\hline $105.80-$ & 107.00 & 2500 & 2630 & 95 & 250 & 35 & 1300 & 89 \\
\hline 107.00- & 108.00 & 1600 & 2000 & 150 & 100 & 15 & 950 & 87 \\
\hline $108.00-$ & 109.00 & 978 & 2250 & 15 & 60 & $<10$ & 1460 & 40 \\
\hline $109.00-$ & 110.00 & 1260 & 1520 & 35 & 100 & $<10$ & 1130 & 59 \\
\hline 110.00- & 111.00 & 1980 & 3460 & 85 & 200 & 105 & 943 & 107 \\
\hline $111.00-$ & 112.35 & 3200 & 4200 & 145 & 400 & 75 & 1150 & 109 \\
\hline $112.35-$ & 114.02 & 979 & 1980 & 70 & 165 & 45 & 1620 & 62 \\
\hline $114.02-$ & 114.64 & 789 & 1620 & $<10$ & $<10$ & $<10$ & 1120 & 46 \\
\hline $114.64-$ & 116.35 & 139 & 977 & $<10$ & 70 & $<10$ & 1080 & 65 \\
\hline $116.35-$ & 117.44 & 651 & 933 & $<10$ & 55 & $<10$ & 1030 & 36 \\
\hline $117.44-$ & 119.00 & 754 & 1330 & 125 & 145 & $<10$ & 914 & 55 \\
\hline 119.00- & 120.00 & 279 & 591 & 65 & $<10$ & $<10$ & 1090 & 43 \\
\hline $120.00-$ & 121.00 & 1410 & 1670 & 60 & 120 & 55 & 939 & 62 \\
\hline $121.00-$ & 122.00 & 1760 & 1010 & 30 & 145 & 390 & 940 & 63 \\
\hline 122.00- & 122.73 & 2470 & 3140 & 75 & $<10$ & 25 & 1020 & 92 \\
\hline 122.73- & 124.00 & 30 & 153 & 170 & $<10$ & $<10$ & 148 & 20 \\
\hline
\end{tabular}

determined by atomic absorption at ISCOR. (Tables 3 and 4). $\mathrm{Cu}, \mathrm{Ni}$ and PGE contents are plotted versus stratigraphic height in BL2 in Figure 4. A more complete set of major and trace elements including $\mathrm{S}$ was obtained for 8 samples using: XRF at the University of Pretoria and, for S, the University of Natal (Table 5). For 7 samples a complete set of PGE+Au analyses was obtained, using INAA at the University of Quebec at

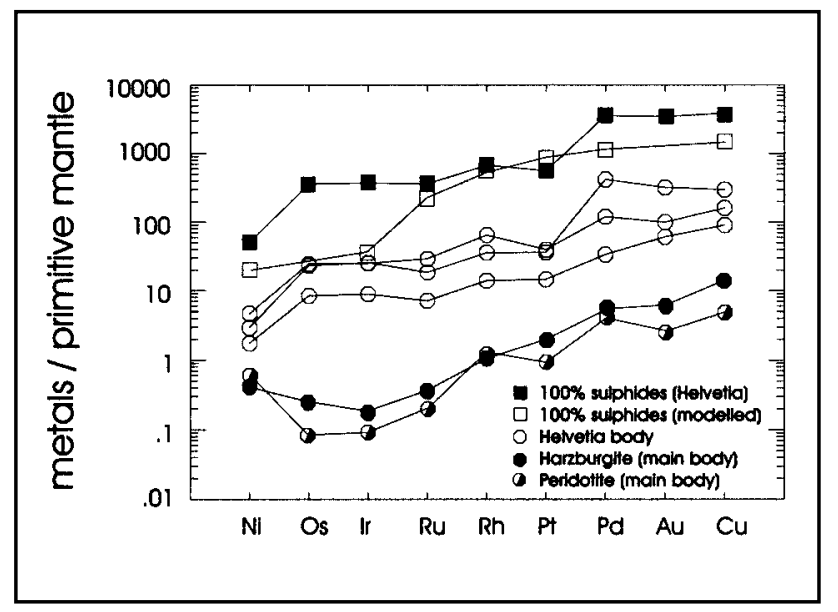

Figure 5. Metal patterns, normalized to primitive mantle, of the analysed samples (including an average of the Helvetia samples recalculated to $100 \%$ sulphide), and of model sulphide melt segregating at an R-factor of 3000 from B1 magma that previously experienced 0.01 weight \% sulphide segregation and 10\% olivine fractionation. D values for the PGE, Cu and $\mathrm{Ni}$ were assumed at 20000, 1000, and 300, respectively. See text for explanation. Normalization factors are from Barnes and Maier (1999).
Chicoutimi after collection of the metals in a Ni-sulphide bead and irradiation in the Slowpoke reactor at Ecole Polytechnique, Montreal (Table 5). For analytical details as well as precision and accuracy, the reader is referred to Maier and Barnes (1999).

The highest concentrations of sulphides were found in boreholes BL1 and BL2, at the base of the lower pyroxenite within the Helvetia body (Figures 3 and 4). The three samples analysed in detail contain between 300 and $2000 \mathrm{ppb}$ PGE, at S contents between 1 and 2.5 weight \%. Metal contents recalculated to 100\% sulphide are listed in Table 6. The data show that the sulphides are highly metal-enriched, containing between 6 and $16 \% \mathrm{Cu}, 9$ and $11.5 \% \mathrm{Ni}$, and 10 to 44 ppm PGE. $\mathrm{Cu} / \mathrm{Ni}$ ratios are broadly at unity, suggesting a $\mathrm{Mg}$ basaltic parental silicate magma. Mantle-normalized metal patterns (Figure 5) show a progressive increase from $\mathrm{Ni}$ to $\mathrm{Cu}$ for the majority of samples, with $\mathrm{Ni} / \mathrm{Ir}_{\mathrm{N}}$ of 0.2 and $\mathrm{Cu} / \mathrm{Pd}_{\mathrm{N}}$ of approximately unity. In the more abundant atomic absorption data, $\mathrm{Cu} / \mathrm{Pd}$ levels are somewhat higher. Average $\mathrm{Pd} / \mathrm{Ir}$ ratios are 11, and $\mathrm{Pt} / \mathrm{Pd}$ is $<1$. Such metal patterns may be explained if (i) the sulphides segregated from undepleted magma at low to moderate R-factors (mass ratio of silicate magma to sulphide melt) where the difference in partitioning between $\mathrm{Cu}, \mathrm{Ni}$ and the PGE is swamped, and (ii) the sulphides underwent insignificant fractionation of monosulphide solid solution (mss) during solidification.

The complete set of platinum-group elements was also analysed in four samples from the main intrusion in borehole BL2. Samples BL2 511.84 and BL2 492.28 from the basal feldspathic harzburgite contain between 23 and 50 ppb PGE at $0.3 \%$ S. Samples BL2 453.9 and 
Table 4. Metal contents in borehole BL2

\begin{tabular}{|c|c|c|c|c|c|c|c|c|}
\hline & & $\mathrm{Cu}$ (ppm) & Ni (ppm) & Pt (ppb) & Pd (ppb) & Au (ppb) & Cr (ppm) & Co (ppm) \\
\hline from & to & & & & & & & \\
\hline 71.00 & 72.00 & 63 & 916 & $<10$ & $<10$ & $<10$ & 1180 & 57 \\
\hline 141.00 & 142.79 & 178 & 110 & $<10$ & $<10$ & $<10$ & 67 & 33 \\
\hline 142.79 & 144.00 & 49 & 1080 & $<10$ & $<10$ & $<10$ & 805 & 52 \\
\hline 144.00 & 145.00 & 54 & 1300 & $<10$ & 25 & $<10$ & 962 & 79 \\
\hline 145.00 & 146.00 & 17 & 1920 & $<10$ & 95 & $<10$ & 1170 & 107 \\
\hline 146.00 & 147.00 & 12 & 1720 & $<10$ & 20 & $<10$ & 1070 & 94 \\
\hline 147.00 & 148.00 & 17 & 1610 & $<10$ & 15 & $<10$ & 1070 & 94 \\
\hline 148.00 & 149.00 & 399 & 1280 & $<10$ & 50 & $<10$ & 1160 & 109 \\
\hline 149.00 & 150.00 & 1720 & 1190 & 80 & 190 & 20 & 573 & 39 \\
\hline 150.00 & 151.00 & 578 & 1130 & 20 & 95 & $<10$ & 1010 & 50 \\
\hline 151.00 & 152.00 & 1850 & 1450 & 55 & 120 & 15 & 1150 & 89 \\
\hline 152.00 & 153.00 & 1290 & 1480 & 100 & 225 & 25 & 1110 & 103 \\
\hline 153.00 & 154.62 & 277 & 539 & $<10$ & 50 & $<10$ & 356 & 34 \\
\hline 154.62 & 156.00 & 453 & 416 & $<10$ & 70 & $<10$ & 46 & 43 \\
\hline 170.00 & 171.00 & 25 & 156 & $<10$ & $<10$ & $<10$ & 140 & 20 \\
\hline 171.00 & 172.00 & 28 & 187 & $<10$ & $<10$ & $<10$ & 144 & 21 \\
\hline 172.00 & 173.00 & 27 & 148 & $<10$ & $<10$ & $<10$ & 140 & 21 \\
\hline 173.00 & 174.00 & 24 & 129 & $<10$ & $<10$ & $<10$ & 136 & 20 \\
\hline 174.00 & 175.00 & 49 & 172 & $<10$ & $<10$ & $<10$ & 145 & 23 \\
\hline 175.00 & 176.00 & 16 & 142 & $<10$ & $<10$ & $<10$ & 144 & 19 \\
\hline 176.00 & 177.00 & 8 & 144 & $<10$ & $<10$ & $<10$ & 140 & 15 \\
\hline 177.00 & 178.00 & 62 & 203 & $<10$ & $<10$ & $<10$ & 134 & 37 \\
\hline 178.00 & 179.00 & 25 & 164 & $<10$ & $<10$ & $<10$ & 233 & 19 \\
\hline 179.00 & 180.00 & 36 & 160 & $<10$ & $<10$ & $<10$ & 129 & 19 \\
\hline 308.00 & 309.00 & 127 & 1640 & 35 & $<10$ & $<10$ & 69 & 126 \\
\hline 344.00 & 345.50 & 57 & 2000 & 20 & $<10$ & $<10$ & 115 & 142 \\
\hline 394.00 & 395.00 & 44 & 1760 & $<10$ & $<10$ & $<10$ & 85 & 137 \\
\hline 427.00 & 428.00 & 182 & 1570 & 15 & $<10$ & $<10$ & 73 & 128 \\
\hline 450.00 & 451.00 & 368 & 1740 & 20 & $<10$ & $<10$ & 83 & 139 \\
\hline 475.00 & 476.00 & 117 & 1310 & $<10$ & $<10$ & $<10$ & 106 & 117 \\
\hline 492.00 & 493.54 & 265 & 1070 & 45 & $<10$ & $<10$ & 153 & 94 \\
\hline 493.54 & 495.00 & 483 & 1030 & $<10$ & $<10$ & $<10$ & 90 & 87 \\
\hline 495.00 & 496.00 & 205 & 1030 & $<10$ & $<10$ & $<10$ & 87 & 92 \\
\hline 496.00 & 497.00 & 194 & 799 & 55 & $<10$ & $<10$ & 59 & 77 \\
\hline 497.00 & 498.00 & 124 & 706 & $<10$ & $<10$ & $<10$ & 68 & 67 \\
\hline 498.00 & 499.00 & 123 & 791 & 15 & $<10$ & $<10$ & 57 & 73 \\
\hline 499.00 & 500.00 & 249 & 922 & $<10$ & $<10$ & $<10$ & 71 & 83 \\
\hline 500.00 & 501.00 & 202 & 1000 & $<10$ & $<10$ & $<10$ & 63 & 89 \\
\hline 501.00 & 502.00 & 150 & 972 & 30 & $<10$ & $<10$ & 61 & 84 \\
\hline 502.00 & 503.00 & 161 & 989 & $<10$ & $<10$ & $<10$ & 77 & 87 \\
\hline 503.00 & 504.00 & 163 & 997 & 15 & $<10$ & $<10$ & 59 & 87 \\
\hline 504.00 & 505.00 & 215 & 989 & $<10$ & $<10$ & $<10$ & 73 & 83 \\
\hline 505.00 & 506.00 & 260 & 1030 & $<10$ & $<10$ & $<10$ & 74 & 84 \\
\hline 506.00 & 507.00 & 259 & 1080 & $<10$ & $<10$ & $<10$ & 64 & 88 \\
\hline 507.00 & 508.00 & 208 & 1110 & $<10$ & $<10$ & $<10$ & 66 & 89 \\
\hline 508.00 & 509.00 & 149 & 938 & $<10$ & $<10$ & $<10$ & 62 & 83 \\
\hline 509.00 & 510.13 & 218 & 866 & $<10$ & $<10$ & $<10$ & 60 & 79 \\
\hline 510.13 & 511.50 & 262 & 714 & 15 & 15 & $<10$ & 64 & 60 \\
\hline 511.50 & 512.00 & 358 & 999 & $<10$ & 15 & $<10$ & 50 & 84 \\
\hline 512.00 & 513.28 & 189 & 529 & $<10$ & $<10$ & $<10$ & 49 & 51 \\
\hline 513.28 & 514.00 & 193 & 853 & $<10$ & $<10$ & $<10$ & 50 & 76 \\
\hline 514.00 & 515.00 & 216 & 958 & $<10$ & $<10$ & $<10$ & 69 & 82 \\
\hline 515.00 & 516.00 & 224 & 909 & $<10$ & $<10$ & $<10$ & 43 & 82 \\
\hline 516.00 & 517.00 & 249 & 952 & 20 & $<10$ & $<10$ & 61 & 81 \\
\hline 517.00 & 517.91 & 225 & 878 & $<10$ & $<10$ & $<10$ & 46 & 80 \\
\hline 517.91 & 519.00 & 201 & 746 & $<10$ & $<10$ & $<10$ & 46 & 67 \\
\hline
\end{tabular}



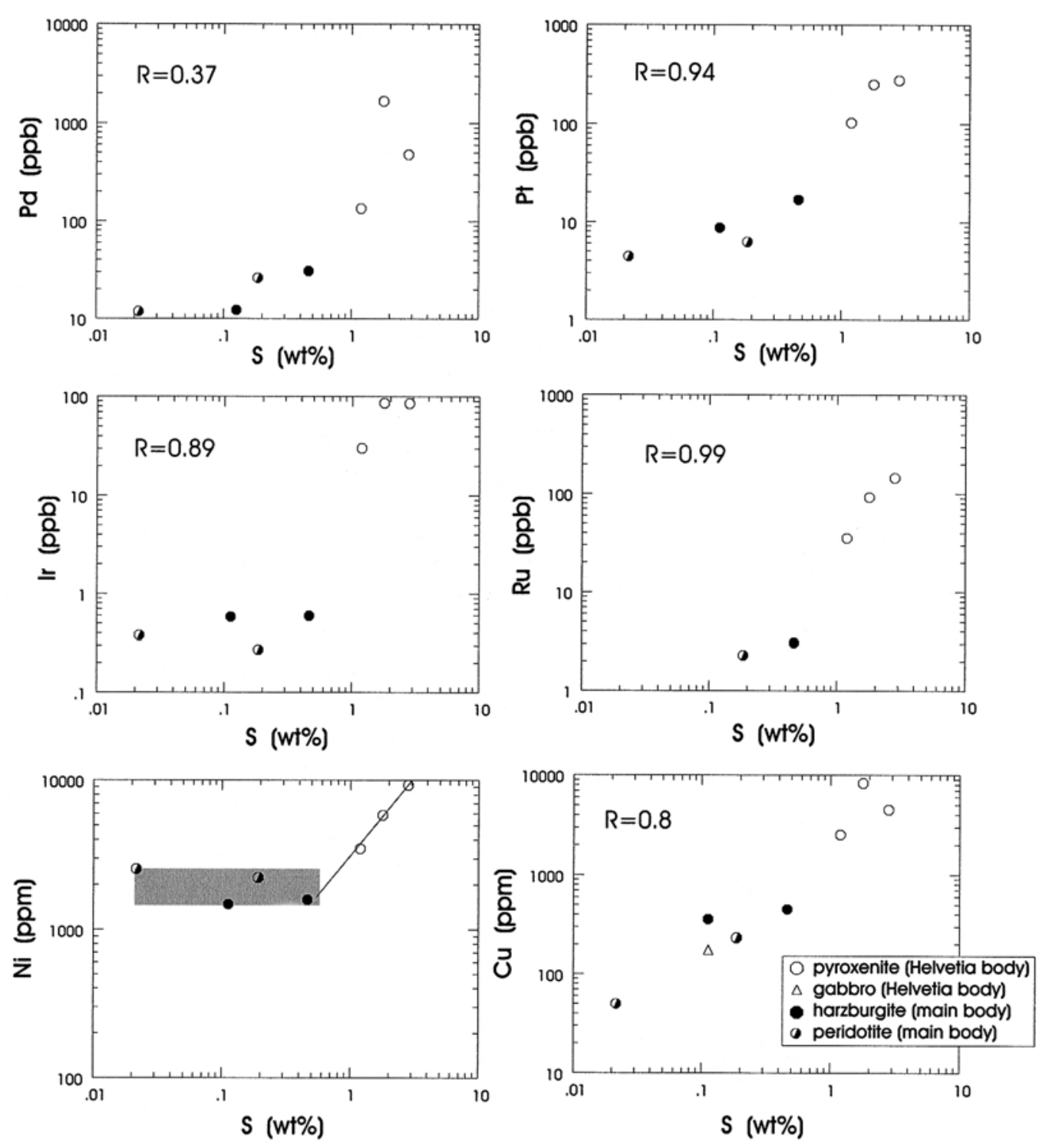

Figure 6. Binary variation diagrams of metals versus S.

413.86 come from the central peridotite and contain between 17 and $35 \mathrm{ppb}$ PGE. The central peridotite contains markedly lower sulphides than the basal harzburgite, at $0.1 \% \mathrm{~S}$. Normalisation of the metal contents to $100 \%$ sulphide (Table 6) suggests that metal tenors of the sulphides in both the harzburgite and the peridotite are considerably lower than those in the Helvetia ores, particularly in terms of the IPGE. As a result, the mantle-normalized PGE patterns of the analysed samples are more fractionated ( $\mathrm{Pd} / \mathrm{Ir} 44)$ than those of the Helvetia body (Pd/Ir 11; Figure 5). However, $\mathrm{Pt} / \mathrm{Pd}$ ratios are similar to those from the Helvetia body. Note that the high $\mathrm{Ni} / \mathrm{Ir}_{\mathrm{N}}$ ratios of the samples analysed from the main body (Figure 5) may be largely attributed to Ni held in silicates (mainly olivine): Figure 6 suggests that the silicates in the harzburgites and peridotites may contain some 1500 to $2500 \mathrm{ppm} \mathrm{Ni}$, respectively, thereby accounting for most of the wholerock $\mathrm{Ni}$. In contrast, $\mathrm{Cu} / \mathrm{Pd}_{\mathrm{N}}$ ratios of the samples are comparable to those of the Helvetia ores, i.e. slightly above primitive mantle levels.

With the exception of $\mathrm{Ni}$ (due to partial olivine and orthopyroxene control), and, to a lesser extent $\mathrm{Pd}$, correlations between the metals and $S$ are good (Figure 6), suggesting that the metals are controlled by sulphides and confirming that the sulphide melt underwent little mss fractionation.

Olivine compositional data were obtained from 5 samples of harzburgite and peridotite from the main body (BL2 303.06, 413.86, 453.9, 492.28, and 511.84), using a CAMECA SX50 electron microprobe at the University of Indiana. Operating conditions for major elements were: acceleration potential $15 \mathrm{kV}$, beam current $20 \mathrm{nA}$, peak counting time 20 seconds, and for Ni: 15 kV, 100 nA, 100 seconds, detection limit 100 ppm. $\mathrm{Ni}$ and $\mathrm{Fo}$ contents of the olivines are listed versus stratigraphic height in Figure 2. The data show a progressive increase in $\mathrm{Fo}$ and $\mathrm{Ni}$ content with height, 
Table 5. Major and trace element concentrations in rocks from boreholes BL1 and BL2

\begin{tabular}{|c|c|c|c|c|c|c|c|c|}
\hline & 105.9 & BL1 107.2 & BL1 111.4 & BL2 107.08 & BL2 413.86 & BL2 453.9 & BL2 492.28 & BL2 511.84 \\
\hline Rock Type & $\mathbf{P x}$ & $\mathbf{P x}$ & $\mathbf{P x}$ & Gab & Per & Per & $\mathbf{H z}$ & $\mathbf{H z}$ \\
\hline $\mathrm{SiO}_{2}$ & 43.77 & 43.53 & 42.60 & 46.87 & 37.24 & 39.43 & 43.79 & 44.08 \\
\hline $\mathrm{TiO}_{2}$ & 0.62 & 0.61 & 0.73 & 2.84 & 0.29 & 0.42 & 1.02 & 0.98 \\
\hline $\mathrm{Al}_{2} \mathrm{O}_{3}$ & 5.43 & 4.50 & 3.86 & 11.04 & 2.46 & 3.35 & 7.12 & 7.85 \\
\hline $\mathrm{Fe}_{2} \mathrm{O}_{3}$ & 16.73 & 15.64 & 18.97 & 18.98 & 18.67 & 18.97 & 17.88 & 16.96 \\
\hline $\mathrm{MnO}$ & 0.11 & 0.14 & 0.13 & 0.31 & 0.23 & 0.23 & 0.22 & 0.20 \\
\hline $\mathrm{MgO}$ & 20.60 & 21.63 & 18.72 & 4.89 & 31.69 & 30.47 & 20.33 & 18.25 \\
\hline $\mathrm{CaO}$ & 3.06 & 4.57 & 6.34 & 9.19 & 1.66 & 2.59 & 5.30 & 5.94 \\
\hline $\mathrm{Na}_{2} \mathrm{O}$ & 0.00 & 0.00 & 0.00 & 1.98 & 0.06 & 0.32 & 1.35 & 2.39 \\
\hline $\mathrm{K}_{2} \mathrm{O}$ & 0.03 & 0.11 & 0.06 & 0.75 & 0.17 & 0.27 & 0.67 & 0.78 \\
\hline $\mathrm{P}_{2} \mathrm{O}_{5}$ & 0.06 & 0.05 & 0.05 & 0.34 & 0.04 & 0.06 & 0.15 & 0.16 \\
\hline $\mathrm{Cr}_{2} \mathrm{O}_{3}$ & 0.25 & 0.27 & 0.45 & $<0.01$ & 0.04 & 0.04 & 0.07 & 0.03 \\
\hline $\mathrm{NiO}$ & 1.12 & 0.53 & 1.09 & $<0.01$ & 0.31 & 0.27 & 0.20 & 0.20 \\
\hline LOI & 6.23 & 6.43 & 5.85 & 0.91 & 7.82 & 2.26 & 0.88 & 1.66 \\
\hline Total & 98.75 & 98.23 & 98.88 & 98.23 & 100.69 & 98.72 & 99.02 & 99.53 \\
\hline $\mathrm{S}(\mathrm{ppm})$ & 16146 & 10832 & 25772 & 1100 & 200 & 1783 & 1100 & 4527 \\
\hline $\mathrm{Cr}$ & 1875 & 1983 & 3041 & 70 & 264 & 253 & 467 & 153 \\
\hline $\mathrm{Ni}$ & 5284 & 3164 & 8478 & 58 & 2355 & 2112 & 1450 & 1547 \\
\hline $\mathrm{Sc}$ & 15 & 21 & 19 & 27 & 2 & 15 & 20 & 15 \\
\hline $\mathrm{V}$ & 123 & 112 & 154 & 441 & 59 & 71 & 148 & 142 \\
\hline $\mathrm{Cu}$ & 7523 & 2303 & 4114 & 170 & 46 & 234 & 349 & 439 \\
\hline $\mathrm{Zn}$ & 265 & 115 & 260 & 213 & 121 & 119 & 115 & 126 \\
\hline $\mathrm{Rb}$ & 3 & 3 & 3 & 35 & 0 & 9 & 24 & 27 \\
\hline $\mathrm{Ba}$ & 16 & 19 & 25 & 246 & 0 & 72 & 187 & 197 \\
\hline $\mathrm{Sr}$ & 16 & 55 & 66 & 216 & 23 & 84 & 207 & 209 \\
\hline $\mathrm{Zr}$ & 72 & 65 & 66 & 201 & 34 & 50 & 124 & 126 \\
\hline Y & 11 & 10 & 14 & 51 & 6 & 8 & 20 & 24 \\
\hline Os (ppb) & 70.8 & 25.8 & 76.2 & 0.0 & $<0.6$ & 0.4 & 1.1 & 0.4 \\
\hline Ir & 77.88 & 27.48 & 78.00 & 0.00 & 0.35 & 0.26 & 0.57 & 0.58 \\
\hline $\mathrm{Ru}$ & 84 & 32 & 133 & na & $<6$ & 2 & $<3$ & 3 \\
\hline $\mathrm{Rh}$ & 30.8 & 12.0 & 55.9 & na & 1.2 & 0.8 & 0.6 & 1.2 \\
\hline $\mathrm{Pt}$ & 227 & 93 & 253 & na & 4 & 6 & 9 & 17 \\
\hline $\mathrm{Pd}$ & 1506 & 122 & 436 & na & 11 & 25 & 12 & 30 \\
\hline $\mathrm{Au}$ & 284.4 & 54.4 & 89.9 & na & 2.3 & 2.1 & 3.2 & 8.3 \\
\hline $\operatorname{Re}$ & 6.7 & 3.7 & 10.6 & na & 0.3 & 0.2 & 0.7 & 1.3 \\
\hline
\end{tabular}

Notes: $\mathrm{Gab}=$ gabbro; $\mathrm{Px}=$ pyroxenite $\mathrm{Hz}=$ harzburgite Per = peridotite na = not analysed

but in general, the olivines appear to be undepleted in Ni. Thus, applying the equations of Hart and Davis (1978) and Roeder and Emslie (1970), olivines in equilibrium with Bushveld parental magmas (between 9 and $12.96 \mathrm{wt} \% \mathrm{MgO}$ and 192 and $295 \mathrm{ppm} \mathrm{Ni}$ for fine- and coarse-grained B1-type sills, respectively; Harmer and Sharpe, 1985; Curl, 2001) can be modelled to have 2472 to $2557 \mathrm{ppm} \mathrm{Ni}$, broadly in the range of the present samples. However, Bushveld magmas should crystallize olivines with Fo contents between 76 and 82, i.e. somewhat higher values than observed in our samples.

\section{Discussion}

Origin of the sulphide mineralization

We attempted to model the composition of the sulphide ores by assuming that they segregated from a parental magma of a similar lineage to Bushveld B1-type magma, which is generally believed to be parental to the lower portions of the Bushveld Complex (Sharpe, 1981; Harmer and Sharpe, 1985). This assumption is based on two main arguments. Firstly, the present intrusions show similarities with the Uitkomst Complex in terms of lithology and compositional features such as metal tenor and $\mathrm{Pt} / \mathrm{Pd}$ ratios of the sulphides. Secondly, a recent study by de Waal et al. (2000) established a common lineage and age for B1 sills and the Uitkomst Complex.

In order to yield sulphides with metal patterns resembling those of the Helvetia ores, the B1 magma would have to have experienced high-R-factor extraction of 0.01 weight $\%$ sulphide melt as well as $10 \%$ olivine fractionation prior to emplacement, followed by sulphide segregation at an R-factor of 3000 (model metal pattern in Figure 5). In view of the relatively low Fo 
Table 6. Metal contents normalized to $100 \%$ sulphide

\begin{tabular}{lrrrrrrrrrr}
\hline Sample name & sulphide & Cu & Ni & Os & Ir & Ru & Rh & Pt & Pd & Au \\
\hline BL1 105.9 & 4.59 & 16.41 & 11.52 & 1544 & 1698 & 1821 & 671 & 4950 & 32841 & 6202 \\
BL1 107.2 & 2.94 & 7.83 & 9.06 & 877 & 934 & 1095 & 408 & 3162 & 4148 & 1850 \\
BL1 111.4 & 7.03 & 5.85 & 11.35 & 1084 & 1110 & 1892 & 795 & 3599 & 6203 & 1279 \\
BL2 413.86 & 0.08 & 5.54 & nd & dl & 422 & dl & 1446 & 4819 & 13253 & 2771 \\
BL2 453.9 & 0.47 & 5.00 & nd & 85 & 56 & 427 & 177 & 1281 \\
BL2 492.28 & 0.37 & 9.38 & nd & 296 & 153 & dl & 161 & 2419 & 3226 \\
BL2 511.84 & 1.21 & 3.63 & 8.96 & 33 & 48 & 248 & 98 & 1405 & 2479 \\
\hline
\end{tabular}

Notes: Ni contents have not been calculated for sulphides from most BL2 samples, due to large potential errors related to low sulphide contents at high olivine contents. Sulphide, $\mathrm{Cu}$ and $\mathrm{Ni}$ contents are in wt $\%$, PGE and Au contents are in ppb.

content of the analysed olivines, this seems a reasonable suggestion. However, figure $7 \mathrm{a}$ shows that the observed sulphide contents of the samples from the Helvetia body are significantly lower than the model sulphide contents, particularly in the case of samples BL1 105.9 (1.6\% S analysed, 15 to 20\% sulphides modelled) and BL1 111.4 (2.58\% S analysed, 40 to 50\% sulphides modelled). A possible explanation is that the ores experienced a large amount of S-loss during alteration, as possibly indicated by the much lower discrepancy between observed and modelled sulphide contents for the less altered samples from the main intrusion. However, the amounts of S-loss required would most likely have resulted in a substantially more altered sulphide assemblage, with phases such as heazlewoodite and FeNi alloys to be expected. Since the sulphide assemblage is essentially primary magmatic, with pyrrhotite, pentlandite and chalcopyrite, substantial S-loss is considered unlikely.

An alternative explanation, modelled in Figure $7 \mathrm{~b}$, could be that the ores segregated from magma that had selectively assimilated $\mathrm{Cu}$ from the country rocks, possibly by means of devolatization of country rock sulphides and introduction of $\mathrm{Cu}$ by hydrothermal fluids. The Lydenburg shale member of the Pretoria Group can contain up to several $100 \mathrm{ppm} \mathrm{Cu}$, although the average value is only $30 \mathrm{ppm}$ (Reczko, 1994). However, the magma is required to contain at least $350 \mathrm{ppm} \mathrm{Cu}$ $(\mathrm{Cu} / \mathrm{Pd} 30000)$ to model the ores, which significantly exceeds $\mathrm{Cu}$ contents of any natural basalt known to us. Secondary $\mathrm{Cu}$ enrichment of the sulphides during alteration could also produce the observed ores, but we would argue that this process would have resulted in highly variable $\mathrm{Cu}$ contents in the sulphides, which is contradicted by the well-defined correlation between $\mathrm{Cu}$ and $\mathrm{S}$ observed in Figure 6.

The trigger for sulphide segregation equally remains unclear at this stage. The occurrence of elevated sulphide concentrations at the basal contact of feldspathic pyroxenite with sulphide-bearing shale in the Helvetia body may suggest a mechanism of in situ contamination with country rock material. The Lydenburg shale Member in the Eastern Transvaal contains an average of $394 \mathrm{ppm} \mathrm{S}$, with individual samples reaching up to 5500 ppm S (Reczko, 1994). This shale may thus be a suitable contaminant to induce sulphide oversaturation. However, in boreholes BL2, BL5 and BL6, sulphide enriched horizons occur within the intrusion (Figure 3). In these cases, interaction with sediments, if any, could not have occurred in situ. Instead, assimilation may have occurred up-flow and the sulphides could have been entrained by distinct magma surges to be deposited in hydraulic traps, as previously modelled for the Voisey's Bay intrusion (Li et al., 2000). Sulphide segregation as a result of mixing of compositionally contrasting magmas flushing through the conduit appears unlikely, in view of the results of $\mathrm{Li}$ et al. (this issue).

\section{Implications for exploration}

Based on the lithological similarities between the maficultramafic intrusion studied here and the Uitkomst Complex, the proximity of both intrusions to a major SE to NW trending set of faults, the broad conformity of the intrusions with the sedimentary country rocks, and compositional features such as similar $\mathrm{Pt} / \mathrm{Pd}$ ratios of the sulphides, the Blaauwboschkraal bodies may form part of a larger conduit system related to the Bushveld magmatic event. This may indicate good potential for sulphides. However, the Blaauwboschkraal bodies intruded at a stratigraphic level within the Transvaal Supergroup that is substantially higher than that of the Uitkomst body, and further geochemical and dating studies are needed to confirm a common magmatic parentage.

In recent years, it has become increasingly clear that in economically mineralised magmatic conduit systems such as Voisey's Bay and Noril'sk, one commonly finds several phases of intrusion, all of them possibly containing magmatic Ni-Cu-(PGE) sulphides, but with contrasting metal tenors. At Voisey's Bay and Noril'sk, the interpretation is that the different lithologies represent different surges of magma exploiting the conduit. Sulphides initially segregated in response to country rock assimilation - either in the conduit or in some staging chamber. These initial sulphides (the protore) commonly have relatively low metal tenors due to low R-factors, but they become significantly upgraded where they were entrained by a subsequent surge of magma streaming through the conduit. Thus, economic 

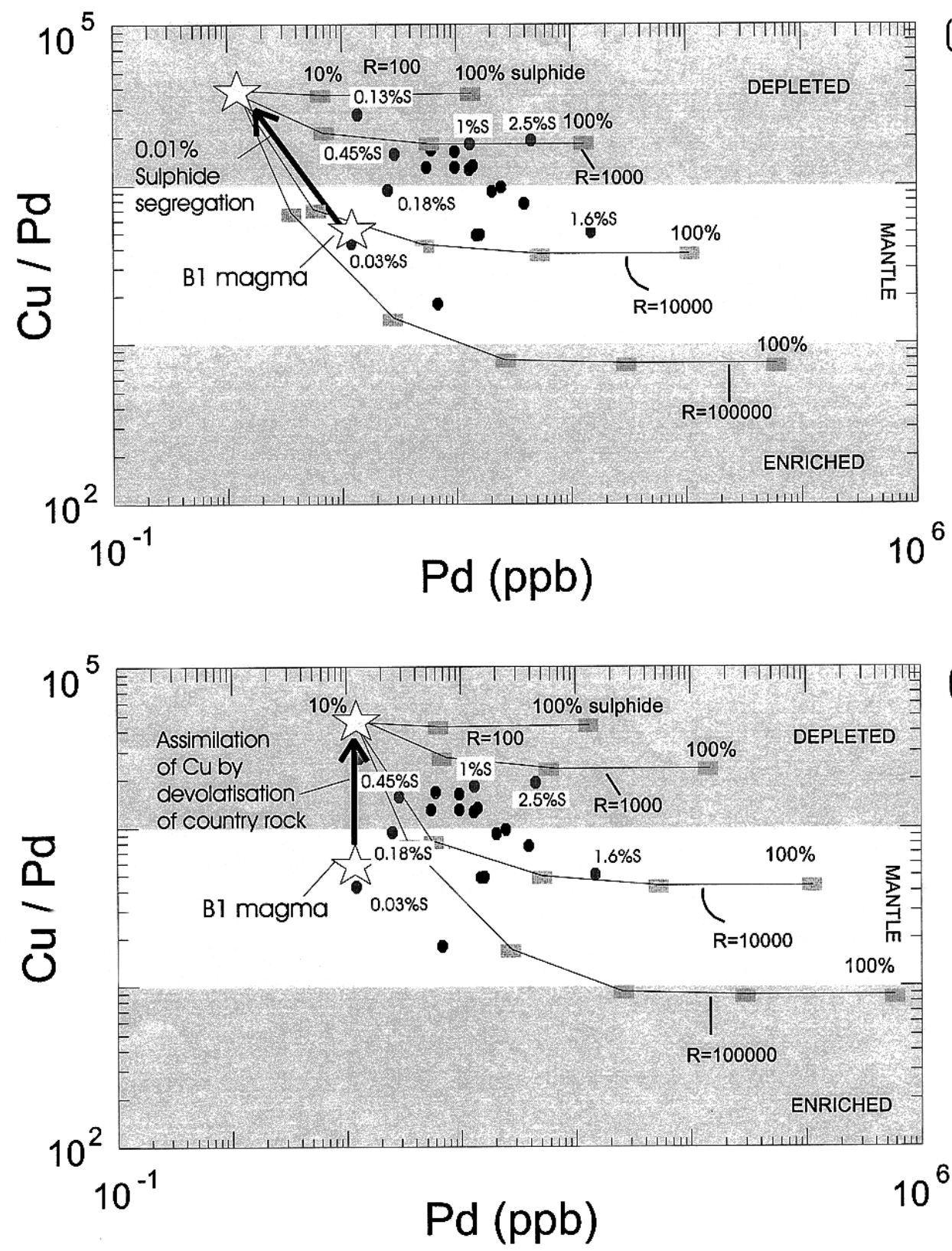

(B)

Figure 7. Diagrams of $\mathrm{Cu} / \mathrm{Pd}$ versus $\mathrm{Pd}$. Tielines are mixing lines between model silicate melt and sulphide melt segregating from the silicate melt at various R-factors. Star symbols represent parental silicate magmas. Black circles represent samples from the Helvetia body, analysed by atomic absorption. Shaded circles with attached S contents represent INAA data. (A) Silicate melt is modelled as Bushveld B1-type magma (Davies and Tredoux, 1985) that experienced 0.01 weight \% sulphide segregation prior to intrusion, using D values between sulphide and silicate melt for $\mathrm{Cu}$ of 1000 and for Pd of 20000. (B) Silicate melt is modelled as B1 magma that selectively assimilated $\mathrm{Cu}$ from the country rocks by means of devolatization. See text for explanation.

sulphide concentrations may not necessarily be found only at the base of conduit systems, but instead at the base of individual flows. We propose that the basal harzburgite, the central peridotite, and the upper pyroxenite of the Blaauwboschkraal bodies represent distinct magma flows streaming through the conduit. This would explain the concentration of sulphides at several levels within the sill (Figure 3, boreholes BL4, 5, and 6). Based on the lack of significant $\mathrm{Ni}$ depletion in the analysed olivines from the basal harzburgite and central peridotite, the sulphides appear to have equilibrated at relatively high R-factors. The potential for significant sulphide ores upstream in the conduit is, however, not necessarily constrained by this, as any 
metal-depleted magmas may have been flushed out of the conduit by later, undepleted, surges of magma. The sulphides may have lagged behind due to their relatively high density, and they may have been upgraded by the undepleted magma surges.

At Voisey's Bay and Noril'sk, economic concentrations of sulphide ores formed where the sulphides entrained by the magma were precipitated in hydrodynamic "traps", e.g. where the conduit widened and the flow velocity of the magma decreased. It is possible that the tongue-like offshoot constituting the Helvetia body may equally represent such a hydrodynamic sulphide trap.

In terms of the model, and by analogy with observations from Voisey's Bay, the metal tenor of the sulphides should increase down-flow. In the absence of metal tenor or mineral chemistry data for all but the BL1 and BL2 boreholes, we cannot determine the flow direction at present.

\section{Acknowledgements}

Funding for this study was provided by a research development grant from the University of Pretoria (to WDM) and by a grant of the National Science and Engineering Research Council of Canada (to SJB). ISCOR granted permission to access their borehole cores and to use their data. R.K.W. Merkle provided valuable input with regard to the sulphide mineralogy. R.E. Harmer and an anonymous referee are thanked for their critical reviews.

\section{References:}

Barnes, S.-J. and Maier, W.D. (1999). The fractionation of $\mathrm{Ni}, \mathrm{Cu}$ and the noble metals in silicate and sulphide liquids. In: Keays, R.R., Lesher, C.M., Lightfoot, P.C. and Farrow, C.E.G. (Eds.), Dynamic processes in magmatic ore deposits and their application to mineral exploration. Geological Association of Canada, Short Course Notes 13, 69-106.

Curl, E. (2001). Parental magmas of the Bushveld Complex, South Africa. $\mathrm{PhD}$ thesis (unpublished). Monash University, Australia, $140 \mathrm{pp}$.
Davies, G. and Tredoux, M. (1985). The platinum-group element and gold contents of the marginal rocks and sills of the Bushveld Complex. Economic Geology, 80, 838-848.

De Waal, S.A., Maier, W.D., Gauert, C.D.K. and Armstrong, R.A. (2001). The age and parental magma of the Uitkomst Complex, South Africa. Cananadian Mineralogist, in 39, 557-571

Gauert, C.D.K., De Waal, S.A. and Wallmach, T. (1995). Geology of the ultrabasic to basic Uitkomst Complex, eastern Transvaal, South Africa: an overview. Journal of African Earth Sciences, 21, 553-570.

Harmer, R.E. and Sharpe, M.R. (1985). Field relations and Strontium isotope systematics of the marginal rocks of the eastern Bushveld Complex. Economic Geology, 80, 813-837.

Hart, S. and Davis, K.E. (1978). Nickel partitioning between olivine and silicate melt. Earth and Planetary Science Letters, 40, 203-219.

Li, C., Lightfoot, P.C., Amelin, Y. and Naldrett, A.J. (2000). Contrasting petrological and geochemical relationships in the Voisey's Bay and Mushuau Intrusions, Labrador, Canada: implications for ore genesis. Economic Geology, 95, 771-799

Li, C., Maier, W.D. and de Waal, S.A. (2001). Magmatic Ni-Cu versus PGE deposits: contrasting genetic controls and exploration implications. South African Journal of Geology, 104, 309-318

Maier, WD, and Barnes, S.-J. (1999). Platinum-group elements in silicate rocks of the Lower, Critical and Main Zones at Union Section, Western Bushveld Complex. Journal of Petrology, 40, 1647-1671.

Maier, W.D., Li, C. and De Waal, S.A. (2001). Why are there no major Ni-Cu sulphide deposits in large layered mafic-ultramafic intrusions? Canadian Mineralogist, 39, 547-556

Naldrett, A.J. (1997). Key factors in the genesis of Noril'sk, Sudbury, Jinchuan, Voisey's Bay and other world-class Ni-Cu-PGE deposits: implications for exploration. Australian Journal of Earth Scence, 44, 283-315.

Reczko, B.F.F. (1994). The geochemistry of the sedimentary rocks of the Pretoria Group, Transvaal Sequence. unpublished. PhD thesis, University of Pretoria, South Africa, 1, 383p, 2, 86p

Roeder, P.L. and Emslie, R.F. (1970). Olivine-liquid equilibrium. Contributions to Mineralogy and Petrology, 71, 257-269.

Schürmann, L.W. (1992). The geochemistry of the Wanhoop multiple intrusion: preliminary results on the genesis of the Uitkomst Complex. Geological Survey of South Africa Report, 1992-0091, 21pp.

Sharpe, M.R. (1981). The chronology of magma influxes to the eastern compartment of the Bushveld Complex as exemplified by its marginal border groups. Journal of the Geological Society of London, 138, 307-326.

Editoral handling: J M. Barton Jr. 